AGRARIS: Journal of Agribusiness and Rural Development Research

Vol. 7 No. 1 January - June 2021,

Pages: 111-126

Article history:

Submitted: July $20^{\text {th }}, 2018$

Accepted: February $1^{\text {st }}, 2021$
Hardiyanti Sultan ${ }^{1, *}$, Dwi Rachmina ${ }^{2}$, Anna Fariyanti²

${ }^{1}$ Faculty of Agriculture Universitas Tadulako, Palu, Central Sulawesi, Indonesia

${ }^{2}$ Department of Agribusiness, Faculty of Economics and

Management, IPB University, Bogor, Indonesia

*)Correspondence email: hardiyantisultan91@gmail.com

\title{
Effect of Transaction Costs on Profit and the Capital Formation of Soybean Farming in Lamongan Regency, East Java
}

\author{
DOI: https://doi.org/10.18196/agraris.v7i1.4427
}

\begin{abstract}
Transaction costs was one of imperfect market characteristic. The transaction costs of soybean farming affected profit level, and profit was one factor of capital formation. This research aimed to analyze the structure and the effect of transaction costs on the profitability and the capital formation of soybean farming. This study applied transaction cost analysis and simultaneous equation as the methods. The respondents were determined using simple random sampling by taking the proportion of $25 \%$ for the three selected districts, resulting in 120 respondents. The data were the transaction costs in 2014/2015 and household data from 2012 to 2014, comprising the assets of land, vehicles, farm equipment, crop, and livestock. The results revealed that the transaction costs were IDR 144,120.86. The negotiation costs became the highest cost component $(60.30 \%)$, followed by information costs $(14.07 \%)$, coordination costs $(12.22 \%)$, implementation costs $(8.03 \%)$, monitoring costs $(4.23 \%)$ and risk costs $(1.15 \%)$. Transaction costs had a significant effect on the profitability of soybean farming. The highest percentage of capital formation on soybean farming was for farmland, reaching $40.43 \%$. Other capitals included vehicles (24.59\%), plants (19.31\%), building (7.37\%), and supporting tools (3.09\%). Transaction costs did not significantly effect on farming capital formation. As a recommendation, collective action was required, farmers should be active on farmers groups to reduce transaction costs.
\end{abstract}

Keywords: capital formation, profit farming, transaction costs

\section{INTRODUCTION}

Transaction costs occur due to imperfect information and limitations in processing the information; thus, increasing the total costs incurred in a business. Transaction costs in some literature are indirect costs, including costs for setting up, conducting, and monitoring transactions (Williamson, 2010). However, it still affects farmers' profits. An increase in transaction costs decreases farmers' welfare both in the lowlands and in the highlands (Fallo, Sinaga, Hartoyo, \& Simatupang, 2020). In several cases concerning trade in goods and services, especially trade on a small scale, such as agricultural products in rural areas, business actors face difficulty identifying transaction costs. The low level of education of business actors in rural areas makes it difficult for them to distinguish or classify all forms of costs that will be or have been incurred (Marimuthu, Arokiasamy, \& Ismail, 2009). 
This identification difficulty reduces the profit they will receive because they unconsciously incur several other costs outside of production costs not considered and previously allocated. Low transaction costs will automatically increase profit, meaning an increase in transaction costs will reduce the profit level (D'Hondt \& Giraud, 2008; Wawondos \& Mustamu, 2014).

The growth rate for capital formation in Indonesia's agricultural sector is relatively low, around 5-10 percent of the total national capital formation in 1951 - 2007 (Eng, 2008). It indicates the weak internal capacity of farming to form individual capital. Likewise, transaction costs in the farming capital formation are rarely carried out, considering the calculation and identification of transaction costs quite challenging.

Being one of the five primary food commodities (rice, corn, soybeans, sugar and beef) in Indonesia, soybean farming was selected as the research object (Statistics Indonesia, 2014). Furthermore, soybeans are the primary source of vegetable protein for most Indonesians. Soybean production until 2013 continued to decline, inversely proportional to its increasing domestic demand; for example, soybean demand in 2010 reached 2,647,151 tons while the production solely reached 907,031 tons (Statistics Indonesia, 2014).

Increased production can be achieved by enhanced productivity and land area. However, agricultural land, including soybean farming, tends to decrease; thus, the effective way to increase production is to enhance productivity. Strengthening or increasing capital or capital formation can be performed to increase business productivity (Kumar, Kumar, \& Mittal, 2004; Kovács, 2018). Increasing capital formation at the farm level will encourage enhanced production through increased farming productivity. Farm productivity was also certainly influenced by working capital, which will indirectly affect farming's capital formation (Prafitri, Rachmina, \& Maulana, 2017).

East Java was one of Indonesia's soybean production centers with the first rank (Agricultural Research and Development, 2020). Most soybean farmers in East Java farm soybean as an intercropping. Soybeans are planted in the second or third planting season after rice or corn plants to eliminate pests' traces and maintain soil fertility. Nonetheless, soybean production also determines the source of farmers' income and directly affects soybean farming activities for the next season.

One of the suppliers of soybeans to East Java was Lamongan Regency. Even though it was not the leading producer, Lamongan Regency was an area that continuously produces soybeans (Statistics Indonesia, 2020). Hence, this regency can represent soybean farming conditions in East Java.

Transaction costs in soybean farming will affect input and output prices. Transaction costs found in both input and output procurement activities. High transaction costs result in a decrease in farmers' profits as business actors (Tahir, Darwanto, Mulyo, \& Jamhari, 2010). Information and negotiation costs were the components of transaction costs mostly found in farming due to information imbalance, one of the market failure characteristics. The highest transaction costs or the most incurred by farmers in farming are information and negotiation costs. Information costs occur due to the unbalanced control of 
information between farmers and traders. This condition also causes farmers to have low bargaining power on output prices to negotiate with traders to get the highest price (Sirajuddin, Siregar, Juanda, \& Dharmawan, 2011; Khapayi \& Celliers, 2016).

High transaction costs lead to market failures and a very low level of corporate profit. Industries locating close to each other or within one reach, between the input producing industry and the processing industry, will reduce transaction costs. Indeed, it is different when the input producing industry is located far from the processing industry. The transaction costs will definitely be greater (Wawondos \& Mustamu, 2014). High transaction costs and inefficient markets are the main reasons for farmers' low prices in several developing countries (Key, Sadoulet, \& Janvry, 2000). The price received by farmers can be higher when they sell to collection centers from supermarkets than to traditional markets due to the higher prices offered by supermarkets (for high-quality products). Moreover, the close location between farmers and the collection centers results in lower transportation costs and commission fees (Nuthalapati, Sutradhar, Reardon, \& Qaim, 2020).

Transaction costs occur more frequently in farms in developing countries with limited access to information. This condition will hamper business actors to form networks that can facilitate the purchase of inputs such as fertilizers and pesticides. Transaction costs arising are transportation costs. The high transportation costs in obtaining these inputs will reduce farming revenue, thereby affecting farming profit (Hardt, 2009).

The relationship between transaction costs and capital formation, in this case farming capital formation, is strongly influenced by farming profit factors and an external factor of credit. These two factors have a significant effect on farming capital formation. The farming capital formation will increase farming productivity, thus achieving higher production (Erden \& Holcombe, 2005). The effect of transaction costs on the capital structure will affect the capital formation in a few years. This effect will impact the company's growth. Low transaction costs will potentially increase company savings. Reduction in transaction costs also impacts the company's decision to invest (Bencivenga, Smith, \& Starr, 1995).

Several previous studies link transaction costs and capital formation occurring in a company. Meanwhile, in this study, the researchers attempted to discover the relationship between transaction costs and capital formation in soybean farming. As previously mentioned, it is assumed that transaction costs will occur more frequently in small-scale businesses in developing countries. The benefits obtained from the transaction costs will affect farming capital formation.

Therefore, this study aims to analyze (1) the transaction cost structure in soybean farming activities; and (2) the effect of transaction costs on profit and the capital formation in soybean farming.

\section{RESEARCH METHOD}

The research location was Lamongan Regency, East Java, purposively selected for being the largest soybean producer in Indonesia. The respondents were determined by simple random sampling with an even proportion distribution for each district. The selected 
districts were three out of 25 districts in Lamongan Regency. This method was utilized due to a sampling frame for each selected district, consisting of 200 soybean farmers in Tikung District, 72 soybean farmers in Kembangbahu District and 208 soybean farmers in Mantup District. Each district was taken as much as 25 percent, resulting in 120 soybean farmers as the respondents, precisely 50 farmers from Tikung District, 18 farmers from Kembangbahu District and 52 farmers from Mantup District.

The data were collected through the survey method. Primary data were obtained through structured questionnaires and interviews. Direct interviews with respondents (soybean farmers) and key informants (farmer group leaders) were performed to get accurate data.

\section{Analysis Technique}

Transaction Cost Analysis (TCA)

\section{Total Transaction Cost Equation}

The calculated component of transaction costs related to soybean farming included both explicit and implicit costs. Each transaction cost was classified for financing soybean farming, affecting either the input or the output price. Transaction costs for input procurement consisted of information, negotiation, coordination and monitoring costs. These costs belonged to explicit costs, which could be directly estimated even though the transaction had not occurred. Transaction costs in input procurement increased input prices, thereby increasing the soybean farming costs. Undoubtedly, high costs influenced the benefits obtained.

Transaction costs in the output procurement consisted of information and risk costs. The transaction costs in procuring output reduced the price of soybean output. Thus, the output price decreased, thereby lessening the profit. Apart from the procurement of inputs and outputs, transaction costs also found in financing sources. Transaction costs in the procurement of financing sources consisted of explicit and implicit costs. The explicit costs included information, negotiation, coordination, monitoring and implementation costs.

Meanwhile, implicit costs included coordination and implementation costs. These costs were classified as implicit costs as they could not be estimated before the transaction occurred, for example, the implementation costs, namely queuing costs. Farmers would have no idea how long they spent queuing. Hence, the estimated costs incurred could not be estimated before the queue occurred. This cost was the income that farmers should obtain from work or activities sacrificed to queue up when handling capital loan documents.

The Equation 1 used to calculate the components of each transaction cost $(\operatorname{TrC})$ was:

$$
\operatorname{Tr} \mathrm{C}=\sum \mathrm{Z}_{\mathrm{i}}
$$

$\mathrm{TrC}$ was the total transaction costs; Zwass a component of transaction costs; $\mathrm{i}$ was a component of transaction costs, consisting of information, negotiation, coordination, implementation, monitoring and risk costs.

The ratio of each component of transaction costs to total transaction costs was calculated using the Equation 2: 


$$
\mathrm{r} Z_{i}=\frac{Z i}{\operatorname{Tr} C}: \sum Z_{i}=1
$$

$\mathrm{rZ}_{\mathrm{i}}$ was the ratio of transaction cost components to total transaction costs, covering information, negotiation, coordination, implementation, monitoring, and risk costs.

\section{The Ratio of Transaction Costs to Farming Profit}

The Equation 3 was applied to determine the proportion of transaction costs to all farming profit:

$$
\operatorname{rTrC} \pi=\frac{\operatorname{TrC}}{\pi} \times 100
$$

$\mathrm{r} \operatorname{TrC} \pi$ was the ratio of transaction costs to profit in percentage; $\Pi$ was the total profit in IDR/year; $\mathrm{TrC}$ was the total transaction costs in IDR/year.

\section{The Ratio of Transaction Costs to Total Farming Costs}

The Equation 4 was implemented to determine the proportion of transaction costs to the total farming costs:

$$
\operatorname{rTrCTC}=\frac{\operatorname{TrC}}{\mathrm{TC}+\operatorname{TrC}} \times 100
$$

rTrCTC was the ratio of transaction costs to total production costs in percentage; TC was the total production costs in IDR/year, and $\operatorname{TrC}$ was the total transaction costs in IDR/year.

\section{Simultaneous Equation Model}

A simultaneous equation model was utilized to examine the factors influencing farming profit and farming capital formation comprising the output price, labor wage price, soybean seed price, fertilizer price, land area, credit, formal and non-formal education, farming experience, and transaction costs. The equation was formulated as Equation 5 and Equation 6:

$$
\begin{aligned}
\text { PROF }= & a_{0}+a_{1} \text { POUT }+a_{2} \text { PWTK }+a_{3} \text { PBEN }+a_{4} \text { PPUK }+a_{5} \text { LHN }+a_{6} \text { CRED }+a_{7} \text { FEDU }+ \\
& a_{8} \text { NFEDU }+a_{9} \text { EXC }+a_{10} \text { TRC }+\mu \\
\text { FCFA }= & b_{0}+b_{1} \text { EXP }+b_{2} \text { LHN }+b_{3} \text { SAV }+b_{4} \text { FEDU }+b_{5} \text { EXC }+b_{6} \text { PROF }+b_{7} \text { TRC }+\mu
\end{aligned}
$$

While, PROF was farming profit (IDR/year), POUT was price of soybean output (IDR/year), PWTK was price of labor wages (IDR/year), PBEN was price of soybean seeds (IDR/year), PPUK was price of chemical fertilizers (IDR/year), LH was land area (Ha), CRED was credit (IDR/year), FEDU was formal education (years), NFED was non-formal education (years), EXC was farming experience (years), TRC was transaction costs (IDR/year), and $\mu$ was error.

The sign and size of the estimated parameters for the first equation are: $a_{0}, a_{1}, a_{5}, a_{6}, a_{7}$, $a_{8}, a_{9}>0$ and $a_{2}, a_{3}, a_{4}, a_{10}<0$ and for the second equation are: $b_{0}, b_{2}, b_{3}, b_{4}, b_{5}, b_{6}>0$ and $b_{1}, b_{7}<0$. 


\section{RESULT AND DISCUSSIONS}

\section{Transaction Cost Structure in Soybean Farming}

Transaction Costs in the Procurement of Financing Sources

The structure of transaction costs for financing soybean farming in Lamongan Regency consisted of (1) information costs, (2) negotiation costs, (3) coordination costs, (4) implementation costs, and (5) monitoring costs.

Information costs are any costs incurred to obtain information regarding business interests, for example, information on price, farming, or financing sources. Negotiation costs are incurred when negotiating with parties who want to work with, for example, the provision of wages for people employed to process loan documents or costs incurred to maintain capital loan contracts on non-formal financing. Coordination costs are incurred when adjusting the agreement between each business actor involved, for example, when taking a loan and returning the loan (Baye, 2010: Williamson, 1989). Implementation costs are incurred for each activity carried out, in this case, the provision of capital loans, for example, administrative costs and costs for processing documents required as a condition for obtaining a capital loan (Coase, 1993). Monitoring costs are incurred due to activities to supervise other parties in implementing contracts (Baye, 2010).

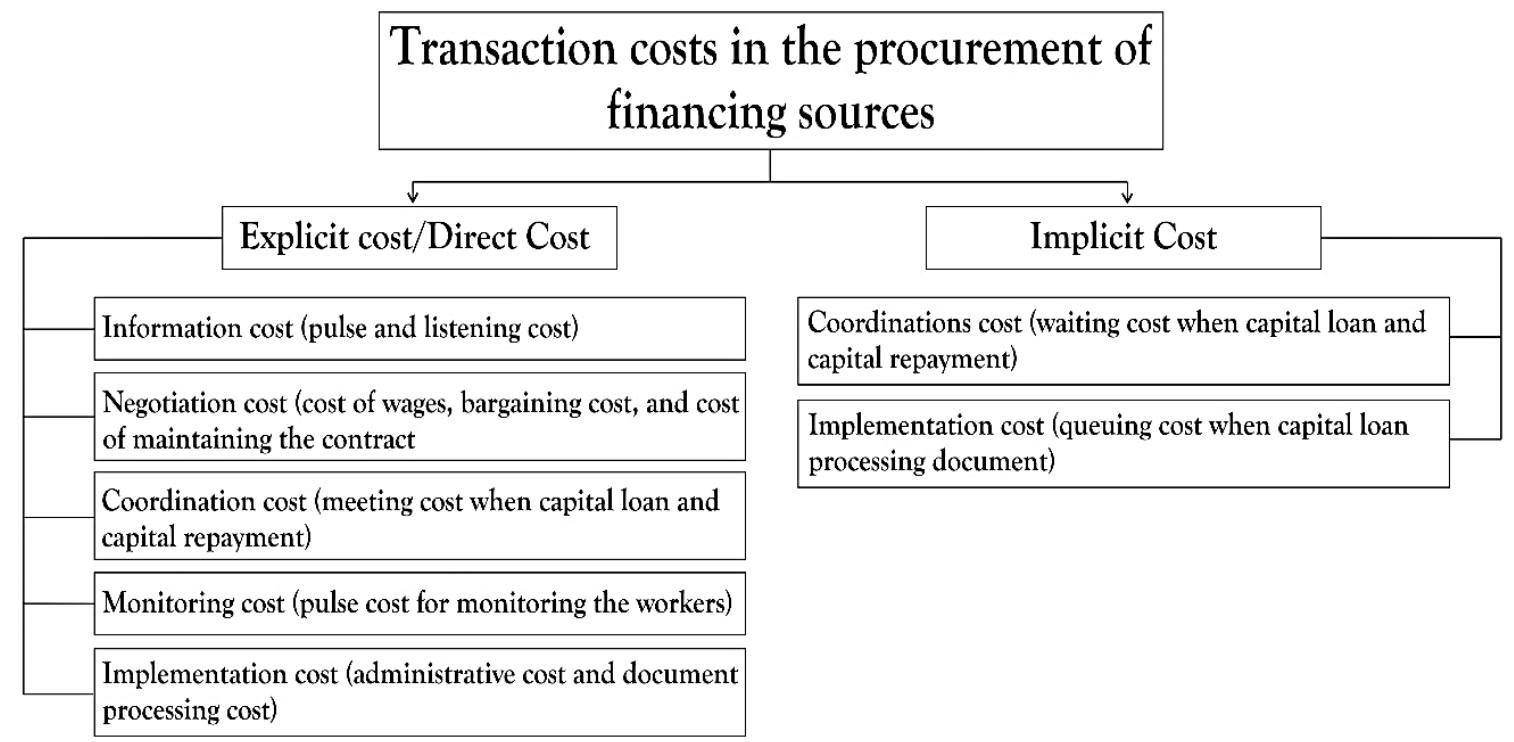

\section{FIGURE 1. THE STRUCTURE OF TRANSACTION COSTS IN THE PROCUREMENT OF FINANCING SOURCES FOR SOYBEAN FARMING IN LAMONGAN REGENCY IN 2014/2015}

The components of the transaction costs in the procurement of financing sources exist in Figure 1 were (1) information costs, consisting of (a) pulse costs, incurred to obtain information on what financing sources were available in Lamongan Regency through electronic intermediaries, such as mobile phone (hand phone). These pulse costs were also incurred when farmers had errand workers, and communicated with them to get all the information the workers had; (b) listening costs, incurred to obtain information on financing sources, for example through conversations in coffee shops with other farmers; (2) 
negotiation costs consisting of (a) the costs of wages, incurred when making payments to people employed to process loan documents; (b) bargaining costs, incurred when bargaining on the amount of the capital loan, usually incurred in informal financing; (c) costs of maintaining the contract, commonly spent on non-formal funding, for example when meeting with the capital owner to extend the capital loan contract; (3) coordination costs, comprising (a) meeting costs when borrowing capital, mainly when farmers took capital lent by financial institutions or capital owners; (b) meeting costs on repayment of capital, incurred when repaying or paying the loan capital; (c) waiting costs when capital loan, belonged to implicit costs, namely costs that could not be directly measured before the event; (d) waiting costs when returning capital, a conversion of the waiting time that farmers spent when returning the capital; (4) implementation costs, consisting of (a) administrative costs, incurred when registering to obtain a capital loan, commonly found in formal financing; (b) document processing costs, the total costs incurred to complete the requirements for obtaining a capital loan, for example, for photocopying files (land ownership certificates, ID cards, family cards, farm information) (c) queuing costs, included in the type of implicit cost, a conversion of the time when queuing for capital loan document processing, and (5) monitoring costs, comprising (a) the pulse costs, allocated for monitoring/supervising the errand workers assigned to take care of complete documents for borrowing capital. Pulse costs were almost incurred for each procurement of financing sources, both formal and non-formal.

These study results are in accordance with the research of Novindra et al., (2019) and Lestari, Prasmatiwi, \& Ismono, (2018), revealing that farmers must pay quite large transaction costs to obtain business capital assistance. The higher the transaction costs of capital assistance, the less the net capital assistance received by farmers, thus reducing the allocation of capital assistance for productive businesses. It resulted in decreased income and welfare of farmers.

\section{Transaction Costs in the Input Procurement of Soybean Farming}

The overall transaction costs of the input procurement affected the soybean input price. Transaction costs increased the soybean input price, resulting in greater input procurement costs. However, soybean farmers did not realize it because they merely counted the real price for farming inputs, while the transaction costs were not calculated.

The several costs in the input procurement of soybean farming described in Figure 2. Farmers incurred information costs on the input provision for soybean farming to learn about soybean farming, for example, farming techniques or how to deal with pests and diseases and find workers outside the family. Those incurring these costs lacked information about what kind of pesticides used to kill pests attacking their soybean crops. The various types of pesticides demand farmers to be selective. Thus, unconsciously, apart from the input price (pesticide), farmers had incurred transaction costs affecting the input price.

The respondent farmers also incurred labor costs to employ outside family workers, usually before the harvest season. The high demand for labor during the harvest season 
triggered farmers to look for once immediately. In the input procurement of soybean farming, there existed negotiation costs in familiarity costs. Farmers incurred these costs to maintain contracts with outside family laborers. They usually invited outside family laborers to have a chat at a coffee shop or a food stall. The farmers paid the entire cost of food and drink, included in the negotiation costs (familiarity costs).

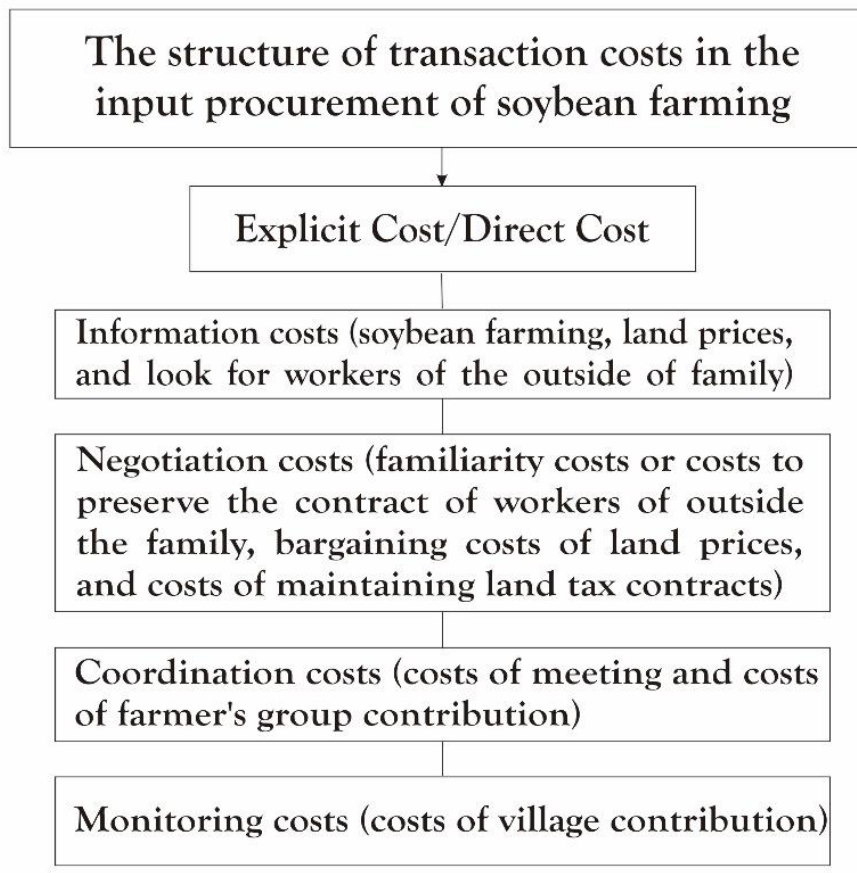

\section{FIGURE 2. THE STRUCTURE OF TRANSACTION COSTS IN THE INPUT PROCUREMENT OF SOYBEAN FARMING IN LAMONGAN REGENCY IN 2014/2015}

Negotiation costs, the costs of maintaining land contracts (land tax), became the largest transaction costs of procuring other inputs. The average cost incurred by respondent farmers was IDR 119,048.5 per hectare. Land and building tax also belongs to transaction costs because the land and building tax nature paid by farmers or landowners maintains their contract for land and buildings from the government (Wawondos \& Mustamu, 2014).

Coordination costs consisted of meeting and farmer group costs. Meeting costs could be defined as the total costs incurred when attending a farmer group meeting, including food and drink costs for farmers' consumption. Costs for farmer group contributions must be paid by the farmer group twice a year. Meanwhile, village costs were incurred once a year and included in monitoring costs, paid to maintain mutual security in one village, and harvest yields and farming equipment owned by farmers.

Transaction Costs in the Output Procurement of Soybean Farming

During the harvest season to post-harvest, farmers carried out several activities that generated transaction costs. One of which was information costs to determine the price of soybeans and the risk affecting the soybean output price (Figure 3). Unfortunately, the respondent farmers did not realize that it would reduce the output price.

When the harvest season came, several farmers looked for information on the price of soybeans prevailing in the market. Farmers seeking this information were those whose 
residences and the land location was far from the district center, making them difficult to obtain any information, including price. Therefore, farmers incurred costs for meeting other farmers or directly meeting district traders. These costs were part of the costs of finding soybean price information.

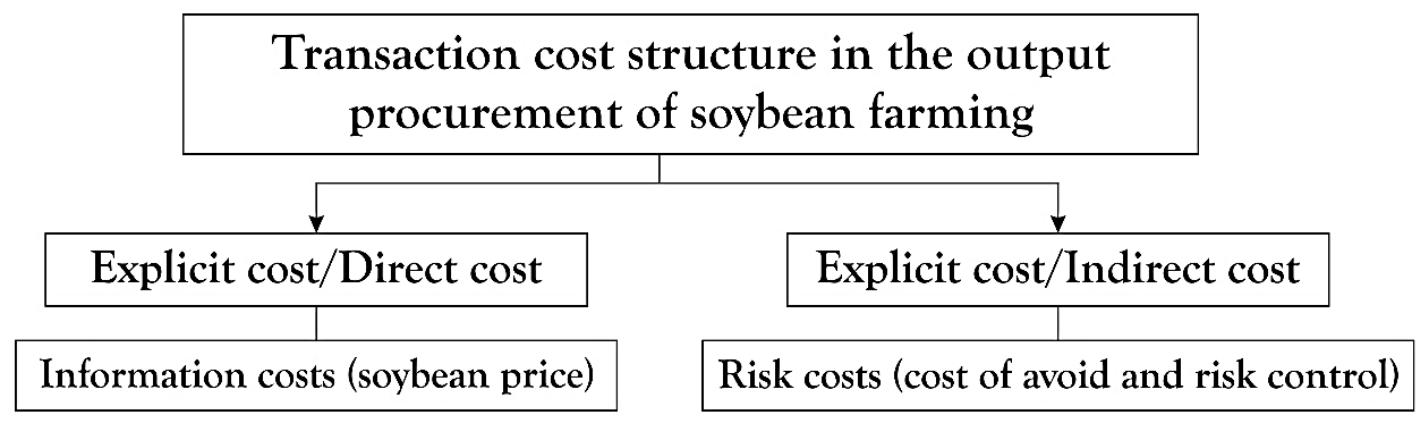

FIGURE 3. TRANSACTION COST STRUCTURE IN THE OUTPUT PROCUREMENT OF SOYBEAN FARMING IN LAMONGAN REGENCY IN 2014/2015

Other types of information costs on output procurement were the costs of contacting other farmers to sell their crops jointly, carried out because the harvest amount did not meet the amount determined by the intermediary traders. If the yield reached one truck or \pm 3 tons, the intermediary traders would pick up the harvest, but the farmers had to deliver it themselves if it did not. Therefore, some farmers with low yields collected their crops to meet these requirements. After that, they contacted the intermediary traders. Costs incurred to find farmers who wanted to sell their produce jointly were included in transaction costs, specifically in information costs.

On the way to intermediary traders, sometimes soybeans were damaged, primarily due to unexpected rainfalls. Therefore, some farmers anticipated it by preparing a medium-sized plastic or tarpaulin to cover the soybeans on their way to the intermediary traders. It was included in risk costs to avoid spoilage of soybeans. However, it was different when the soybeans were damaged when they arrived at the intermediary traders. The price received automatically decreased.

This lost price belonged to the costs of risk control. A total of six respondent farmers, or 5 percent, spent risk control costs to overcome damaged soybeans. The addition of transaction costs to the output price resulted in the decreased output price, causing it to be lower than the actual price.

When viewed from the land area, transaction costs for soybean farming was IDR $144,120.86$ per hectare. Negotiation costs of 60.30 percent dominated the transaction cost component for each procurement activity of financing sources, inputs, outputs and other activities (Table 1). These results are in line with research of Fadhiela, Rachmina, \& Winandi, (2018) which was found that the largest component of transaction costs in output procurement activities is negotiation costs of 82.10 percent. The costs of maintaining land contracts (land tax) were the main factor determining the value of this transaction cost component. The obligation of farmers to pay land and building tax indicates that they will always hold negotiations with the government, allowing them to continue maintaining the land and buildings they own. 
TABLE 1. TOTAL TRANSACTION COSTS OF SOYBEAN FARMING IN LAMONGAN REGENCY IN 2014/2015

\begin{tabular}{|c|c|c|c|c|c|}
\hline $\begin{array}{c}\text { Types of transaction } \\
\text { costs }\end{array}$ & $\begin{array}{l}\text { Procurement of financing } \\
\text { sources }\end{array}$ & $\begin{array}{l}\text { Procurement of } \\
\text { inputs }\end{array}$ & $\begin{array}{c}\text { Procurement of } \\
\text { outputs }\end{array}$ & $\begin{array}{l}\text { Total } \\
\text { (IDR) }\end{array}$ & $\begin{array}{l}\text { Percentage } \\
(\%)\end{array}$ \\
\hline Information costs & & & & & \\
\hline $\begin{array}{l}\text { - Explicit/direct cost } \\
\text { Negotiation cost }\end{array}$ & $17,317.08$ & $2,512.50$ & $1,308.33$ & $20,275.42$ & 14.07 \\
\hline $\begin{array}{l}\text { - Explicit/direct cost } \\
\text { Coordination costs }\end{array}$ & $4,108.33$ & $82,800.00$ & - & $86,908.33$ & 60.30 \\
\hline - Explicit/direct cost & $6,175.00$ & $11,033.33$ & - & $17,208.33$ & - \\
\hline $\begin{array}{l}\text { - Implicit cost } \\
\text { Implementation costs }\end{array}$ & 401.28 & - & - & 401.28 & 12.22 \\
\hline - Explicit/direct cost & $10,510.83$ & - & - & $11,373.33$ & - \\
\hline - Implicit cost & 201.25 & - & - & 201.25 & 8.03 \\
\hline Monitoring costs & & & & & \\
\hline $\begin{array}{l}\text { - Explicit/direct cost } \\
\text { Risk costs }\end{array}$ & 469.58 & $5,625.00$ & - & $6,094.58$ & 4.23 \\
\hline - Explicit/indirect cost & - & - & $1,658.33$ & $1,658.33$ & 1.15 \\
\hline Total transaction costs & $39,183.35$ & $101,970.80$ & $2,966.66$ & $144,120.86$ & 100.00 \\
\hline
\end{tabular}

The tax is a type of unavoidable transaction costs, meaning it must be incurred. In several cases, especially in Indonesia, there is a Minister of Finance Regulation Number 159 of 2015 on providing a tax holiday or tax deduction for nine industrial sectors, including the agricultural sector. A tax deduction is only granted for large-scale industries. The conditions that must be met are that the industry can earn a minimum of IDR 1 trillion with a minimum number of employees of 500 people. This tax holiday is intended to attract investors to invest more in the industrial sectors in question.

In the case of farming, especially small-scale farming, the possibility of giving a tax cut policy is so small. It is because small-scale farming not considered an industry, and the income does not reach the specified target, even if it is seen from the number of workers that can reach 500 people if all farmers empower farmer groups. If a farmer group is formed and there is a collective action, efforts to reduce land tax can be submitted to the Ministry of Finance. The impact generated, especially on transaction costs, namely the land tax's negotiation costs, can be minimized.

The transaction cost component with the largest percentage after the negotiation costs was information costs. Information costs dominated almost all activities carried out by farmers during soybean farming, for example, in the procurement of financing sources, inputs and outputs. Information costs for farming had a percentage of 14.07 percent. The lack of access to get information demanded farmers to always pay for information. Even so, the costs incurred were sometimes not yet known by farmers. These expenses were not calculated as other farming costs. This study's results are in line with the study of Hung \& Khai, (2020) revealing that the most considerable transaction costs in chili farming in Tra Vinh, Vietnam was the negotiation costs due to the need to find the best trade route for chili marketing, requiring negotiation with several traders. In this study, information costs were also the second-largest transaction costs after negotiation costs, followed by monitoring costs, risk costs and socio-economic costs. Besides, Nasir \& Qori'ah, (2020) also 
demonstrated the high negotiation costs on cassava farming in Jember, Central Java. The biggest negotiation costs occurred during Ramadhan and Idul Fitri's months because farmers tried to find traders who could provide the best price for their cassava.

\section{The Effect of Transaction Costs on the Profit of Soybean Farming}

After knowing the structure of transaction costs in soybean farming, the next research objective was to determine the effect of transaction costs on soybean farming profit.

Table 2 presents the revenue from soybean farming consisting of income from both soybeans and intercropping plants of corn or green beans. Farming costs covered both soybean and intercropping farming. Thus, the average profit obtained for one hectare in one year of soybean farming is IDR 3,685,282.39.

TABLE 2. REVENUE AND PROFIT OF SOYBEAN FARMING IN LAMONGAN REGENCY IN 2014/2015

\begin{tabular}{lcrr}
\hline \multicolumn{1}{c}{ Variables } & Unit & \multicolumn{2}{c}{ Total (IDR) } \\
\hline Soybean production & $\mathrm{Kg}$ & $1,539.08$ & \\
Soybean price & IDR/Kg & $6,683.33$ & \\
Soybean income & IDR & & $10,184,200.00$ \\
Intercropping production & $\mathrm{Kg}$ & 222.63 & \\
Intercropping price & IDR/Kg & $1,270.83$ & \\
Intercropping income & IDR & $556,562.50$ \\
Soybean farming income & IDR & $10,740,762.50$ \\
Soybean farming costs & IDR & $7,055,480.11$ \\
\hline Soybean farming profit & IDR & $3,685,282.39$ \\
\hline
\end{tabular}

Table 3 depicts that the factors with a significant effect on the 10 percent level were the variables of labor wages, price of seeds, fertilizer price, land area, credit, non-formal education and transaction costs. In contrast, the factors with no significant effect were the variables of output price, formal education and farming experience. This is not in line with Rachmina, Daryanto, Tambunan, \& Hakim (2014) research which found that farmer education is an important factor that is very effective in increasing farming profits.

TABLE 3. ESTIMATION RESULTS OF FARMING PROFIT EQUATION PARAMETER IN SOYBEAN FARMING IN LAMONGAN REGENCY IN 2014/2015

\begin{tabular}{lrrrc}
\hline \multicolumn{1}{c}{ Variables } & Estimated Parameters & Standard Error & TValue & $\operatorname{Pr}>|\mathrm{t}|$ \\
\hline Constant & $41,146,509.00$ & $35,059,891.00$ & 1.17 & 0.24 \\
Output price & $1,018.98$ & $2,931.31$ & 0.35 & 0.73 \\
Labor wages & -0.86 & 0.17 & -5.03 & $<.00$ \\
Price of seeds & -19.71 & 7.47 & -2.64 & 0.00 \\
Fertilizer price & $-6,871.46$ & $3,419.58$ & -2.01 & 0.04 \\
Land area & $7,711,857.00$ & $1,749,396.00$ & 4.41 & $<.00$ \\
Credif & 27.52 & 12.42 & 2.22 & 0.03 \\
Formal education & $-301,793.00$ & $238,783.30$ & -1.26 & 0.21 \\
Non-formal education & $4,893,805.00$ & $1,408,824.00$ & 3.47 & 0.00 \\
Farming experience & $46,522.66$ & $59,674.84$ & 0.78 & 0.44 \\
Transaction costs & -7.57 & 2.28 & -3.31 & 0.00 \\
\hline
\end{tabular}

The transaction costs variable had a negative and significant effect on the soybean farming profit. The transaction cost component with the highest percentage was negotiation 
costs of 60.30 percent of the total transaction costs, as seen in Table 1. Regarding the transaction cost structure, the transaction costs in the procurement of inputs, outputs, and financing sources harmed soybean farming profit. Transaction costs could affect profit by indicating no concentration of activities at one point (agglomeration). It results in a market failure and a very low business profit decline.

\section{The Effect of Transaction Costs on the Capital Formation of Soybean Farming}

A capital formation is an effort to add assets either quantitatively or qualitatively. In farming, capital formation is also called private capital formation. This study analyzed the capital formation patterns in fixed assets in 3 years, from 2012 to 2014.

TABIE 4. THE CAPITAL FORMATION OF SOYBEAN FARMING IN LAMONGAN REGENCY IN 2014/2015

\begin{tabular}{clrc}
\hline No & Types of Assets & Total (IDR) & Percentage (\%) \\
\hline 1. & Farmland & $3,412,500$ & 40,43 \\
2. & Building & 622,059 & 7,37 \\
3. & Vehicle & $2,075,450$ & 24,59 \\
4. & Farm equipment & & \\
& - Hand sprayer & 127,917 & 1,51 \\
& - Hoe & 45,625 & 0,54 \\
& - Sickle & 33,625 & 0,39 \\
& - Tarpaulin & 6,347 & 0,07 \\
& - Basket & 49,500 & 0,58 \\
5. & Plant & $1,630,339$ & 19,31 \\
\hline & Total & $8,438,803$ & 100,00 \\
\hline
\end{tabular}

Table 4 reports that the capital formation for farming land had the highest percentage of 40.43 percent. The addition or maintenance of land was not carried out intensively by the respondent farmers at the research location. Only a few of them added land for soybean farming. These farmers included farmers with broad land categories. Meanwhile, farmers with narrow and medium land categories were likely not to add land for soybean farming in a 3-year-period. They tended to sell their land because of other interests such as household affairs, celebration needs or hospital fees. This study's results align with Rachmina, Daryanto, Tambunan, \& Hakim, (2014) discovering that the highest capital formation was farming land. The addition of land occurred because of an initiative to make long-term investments. Moreover, Erden \& Holcombe, (2005) argued that additional land could also occur due to increased household savings. The increase in savings caused farmers to prefer to buy land instead of buying other assets.

The estimation results to determine the factors influencing the capital formation of soybean farming in the study location are presented in Table 5. The factors with a significant effect on the ten percent level on the capital formation were household expenses, land area, farming experience and farming profit. Conversely, the factors with no significant effect were savings, formal education and transaction costs.

The estimation results for the transaction costs did not significantly affect the farming capital formation. It contrasts with the research of Bencivenga et al., (1995); Erden \& Holcombe, (2005); Dao, (2008), who found a positive and significant effect of transaction 
costs on capital formation. The higher the transaction costs incurred, the lower the level of capital formation for a business.

\section{TABIE 5. ESTIMATION RESULTS OF EQUATION PARAMETER OF THE CAPITAL FORMATION IN SOYBEAN FARMING IN LAMONGAN REGENCY IN $2014 / 2015$}

\begin{tabular}{lrrrc}
\hline \multicolumn{1}{c}{ Variables } & $\begin{array}{c}\text { Estimated } \\
\text { Parameters }\end{array}$ & Standard Error & t Value & $\operatorname{Pr}>|\boldsymbol{t}|$ \\
\hline Constant & $-250,943.00$ & $5,015,505.00$ & -0.05 & 0.96 \\
Household expenses & -0.47 & 0.29 & -1.61 & 0,10 \\
Land area & $7,332,617.00$ & $2,453,607.00$ & 2.99 & 0.00 \\
Savings & 0.70 & 0.87 & 0.80 & 0.42 \\
formal education & $-198,123.00$ & $325,879.90$ & -0.61 & 0.54 \\
Farming experience & $162,507.70$ & $86,173.12$ & 1.89 & 0.06 \\
Farming profit & 0.22 & 0.17 & 1.32 & 0.03 \\
Transaction costs & -4.23 & 2.80 & -1.51 & 0.13 \\
\hline
\end{tabular}

Due to the meagre transaction costs for soybean farming, IDR $144,120.86$ per year, while the profit was IDR 3,685,282.39 per year. The ratio of transaction costs to farming profit was only 3.91 percent. Hence, even though it had a significant effect on farming profit, transaction costs would not significantly affect farming capital formation. This study's results are inconsistent with the study of Herdiansyah, Negoro, Rusdayanti, \& Shara, (2020), which found that transaction costs significantly affected profit and the farming capital formation in oil palm plantations. It was because farmers worked together or took collective action with the Village Unit Cooperative, which caused large and small transaction costs on profit and farming capital formation.

\section{CONCLUSION}

Based on the result of the research, found that the transaction cost structure of soybean farming in Lamongan Regency was divided into three main activities: (1) transaction costs for the procurement of financing sources, consisting of information costs, negotiation costs, coordination costs, implementation costs and monitoring costs; (2) transaction costs for input procurement, comprising information costs, negotiation costs, coordination costs and monitoring costs; (3) transaction costs in the output procurement, consisting of information and risk costs. The TCA shows that transaction costs had a negative and significant effect on the soybean farming profit. Conversely, transaction costs did not have a significant effect on capital formation. It was due to the very low transaction costs. Therefore, although they had a significant effect on farming profit, they did not significantly affect farming capital formation. As a recommendation, collective action is required to reduce transaction costs. Farmers can carry it out by being actively involved in farmer groups for every farming activity, either in the procurement of financing sources, inputs or outputs.

\section{ACKNOWLEDGMENT}

The authors would like to thank the Agribusiness Department, which has provided the opportunity for writers to participate in the Leading Research of the Agribusiness 
Department (PUD), Faculty of Economics and Management, IPB University, so that with this participation, the authors obtained assistance in research funds and research data.

\section{REFERENCES}

Agricultural Research and Development. (2020). Indonesia's soybean production in Indonesia. East Java: Badan Penelitian dan Pengembangan Indonesia.

Baye, M. R. (2010). Managerial Economics and Business Strategy. New York: Mc Graw-Hill Companies Inc.1221 Avenue of the America's.

Bencivenga, V. R., Smith, B. D., \& Starr, R. M. (1995). Transactions Costs, Technological Choice, and Endogenous Growth. Journal of Economic Theory, 67(1), 153-177. https://doi.org/10.1006/jeth.1995.1069

Coase, R. H. (1993). Coase on Posner on Coase: Comment. Journal of Institutional and Theoretical Economics (JITE), 149(1), 96-98.

D’Hondt, C., \& Giraud, J. R. (2008). Transaction Cost Analysis A-Z. France: EDHEC.

Dao, M. Q. (2008). The Impact of Investment Climate Indicators on Gross Capital Formation in Developing Countries. The Journal of Developing Areas, 42(1), 155-163.

Eng, P. van der. (2008). Capital Formation and Capital Stock in Indonesia, 1950-2007 (Working Papers in Trade and Development No. 2008/24). Camberra.

Erden, L., \& Holcombe, R. G. (2005). The Effects of Public Investment on Private Investment in Developing Economies. Public Finance Review, 33(5), 575-602. https://doi.org/10.1177/1091142105277627

Fadhiela, K., Rachmina, D., \& Winandi, R. (2018). Biaya Transaksi dan Analisis Keuntungan Petani pada Sistem Resi Gudang Kopi Arabika Gayo di Kabupaten Aceh Tengah. Jurnal Agribisnis Indonesia, 6(1), 49-60. https://doi.org/10.29244/jai.2018.6.1.49-60

Fallo, F. A. I., Sinaga, B. M., Hartoyo, S., \& Simatupang, P. (2020). Dampak Peningkatan Biaya Transaksi terhadap Kesejahteraan Rumahtangga Petani pada Dataran Rendah dan Tinggi di Nusa Tenggara Timur. Jurnal Ekonomi Pertanian Dan Agribisnis, 4(1), 111-122. https://doi.org/10.21776/ub.jepa.2020.004.01.11

Hardt, L. (2009). The History of Transaction Cost Economics and Its Recent Developments. Erasmus Journal for Philosophy and Economics, 2(1), 29-51. https://doi.org/10.23941/ejpe.v2i1.22

Herdiansyah, H., Negoro, H. A., Rusdayanti, N., \& Shara, S. (2020). Palm oil plantation and cultivation: Prosperity and productivity of smallholders. Open Agriculture, 5(1), 617-630. https://doi.org/10.1515/opag-2020-0063

Hung, P. Q., \& Khai, H. V. (2020). Transaction cost, price risk perspective and marketing channel decision of small-scale chili farmers in Tra Vinh Province, Vietnam. Asian Journal of Agriculture and Rural Development, 10(1), 68-80. https://doi.org/10.18488/journal.1005/2020.10.1/1005.1.68.80 
Key, N., Sadoulet, E., \& Janvry, A. De. (2000). Transactions Costs and Agricultural Household Supply Response. American Journal of Agricultural Economics, 82(2), 245259. https://doi.org/10.1111/0002-9092.00022

Khapayi, M., \& Celliers, P. R. (2016). Factors limiting and preventing emerging farmers to progress to commercial agricultural farming in the King William's Town area of the Eastern Cape Province, South Africa. South African Journal of Agricultural Extension (SAJAE), 44(1), 25-41. https://doi.org/10.17159/2413-3221/2016/v44n1a374

Kovács, G. (2018). Methods for Efficiency Improvement of Production and Logistic Processes. Research Papers Faculty of Materials Science and Technology Slovak University of Technology, 26(42), 55-61. https://doi.org/10.2478/rput-2018-0006

Kumar, P., Kumar, A., \& Mittal, S. (2004). Total Factor Productivity of Crop Sector in the Indo-Gangetic Plain of India: Sustainability issues revisited. Indian Economic Review, XXXIX(1), 169-201.

Lestari, D. A. H., Prasmatiwi, F. E., \& Ismono, R. H. (2018). Analisis Perbandingan Biaya Transaksi, Pendapatan, dan Kesejahteraan Petani Kelapa Sawit Plasma dengan Swadaya di Kabupaten Tulang Bawang. AGRARIS: Journal of Agribusiness and Rural Development Research, 4(2), 111-119. https://doi.org/10.18196/agr.4266

Marimuthu, M., Arokiasamy, L., \& Ismail, M. (2009). Human Capital Development and Its Impact on Firm Performance: Evidence from Developmental Economics. Journal of International Social Research, 2(8) 265-272.

Nasir, M. A., \& Qori'ah, C. G. (2020). Transaction Cost and Market Development of Cassava Production in Jember Regency, East Java, Indonesia. In M. Rondhi \& H. S. Addy (Eds.), The 3rd International Conference on Agricultural and Life Sciences (ICALS 2019) (Vol. 142, p. 05005). Jember: E3S Web of Conferences. https://doi.org/10.1051/e3sconf/202014205005

Novindra, N., Sinaga, B. M., Hartoyo, S., DeRosari, B. B., Hastuti Hastuti, Fallo, F. A. I., \& Amanda, D. (2019). Dampak Bantuan Penanggulangan/Pengentasan Kemiskinan terhadap Produksi, Pendapatan dan Kesejahteraan Rumah Tangga Petani. Journal of Agriculture, Resource and Environmental Economics, 2(1), 88-99. https://doi.org/10.29244/jaree.v2i1.25977

Nuthalapati, C. S. R., Sutradhar, R., Reardon, T., \& Qaim, M. (2020). Supermarket procurement and farmgate prices in India. World Development, 134, 105034. https://doi.org/10.1016/j.worlddev.2020.105034

Prafitri, T., Rachmina, D., \& Maulana, T. N. A. (2017). The Effect of Working Capital on The Profitability of Palm Oil Plantation Companies. Indonesian Journal of Business and Entrepreneurship, 3(2), 111-120. https://doi.org/10.17358/ijbe.3.2.111

Rachmina, D., Daryanto, A., Tambunan, M., \& Hakim, D. B. (2014). Impact of Infrastructure on Profit Efficiency of Vegetable Farming in West Java, Indonesia: Stochastic Frontier Approach. Journal of International Society for Southeast Asian Agricultural Sciences (ISSAAS), 16(2), 116-125. 
Sirajuddin, S. N., Siregar, H., Juanda, B., \& Dharmawan, A. H. (2011). Pengaruh Biaya Transaksi terhadap Sistem Usaha Sapi Perah di Propinsi Sulawesi Selatan. Jurnal Ilmu Dan Teknologi Peternakan, 1(2), 129-137.

Statistics Indonesia. (2014). The production of Soybean in Indonesia. Jakarta: BPS-Statistics Indonesia.

Statistics Indonesia. (2020). The producers of Soybean in East Java. East Java-BPS-Statistics East Java.

Tahir, A. G., Darwanto, D. H., Mulyo, J. H., \& Jamhari, N. (2010). Analisis Efisiensi Produksi Sistem Usahatani Kedelai di Sulawesi Selatan. Jurnal Agro Ekonomi, 28(2), 133-151. https://doi.org/10.21082/jae.v28n2.2010.133-151

Wawondos, R., \& Mustamu, R. H. (2014). Analisis Implementasi Prinsip-Prinsip Good Corporate Governance Pada Perusahaan Bidang Cargo Di Surabaya. AGORA, 2(2).

Williamson, O. E. (1989). Chapter 3 Transaction Cost Economics. In Handbook of Industrial Organization (pp. 135-182). Elsevier. https://doi.org/10.1016/S1573-448X(89)01006-X

Williamson, O. E. (2010). Transaction Cost Economics: The Natural Progression. American Economic Review, 100(3), 673-690. https://doi.org/10.1257/aer.100.3.673 